long periods of time, creating a temperature history that needs to be accounted for when modelling microbial responses to warming over long periods of time.

Allison and co-workers show that microbial physiology could prove critical for understanding soil responses to warming. Future investigations will require detailed information about the microbes themselves; can we observe changes in what they are and which enzymes they produce? Fortunately, methodological advances will make such observations standard procedures. For now, it is clear that our view of how microbes drive the decomposition of soil organic matter is rapidly changing.

Göran I. Ågren is in the Department of Ecology, Swedish University of Agricultural Sciences, Uppsala, Sweden.

e-mail: Goran.Agren@ekol.slu.se
References

1. Schimel, D. S. Glob. Change Biol. 1, 77-91 (1995)

2. Kirschbaum, M. U. F. Soil Biol. Biochem.

38, 2510-2518 (2006)

3. Melillo, J. M. et al. Science 298, 2173-2176 (2002).

4. Eliasson, P. E. et al. Glob. Change Biol. 11, 167-181 (2005)

$\square \quad$ 5. Allison, S. D., Wallenstein, M. D. \& Bradford, M. A. Nature Geosci. 3, 336-340 (2010).

6. Kirschbaum, M. U. F. Glob. Change Biol. 10, 1870-1877 (2004)

7. Balser, T. C. \& Wixon, D. L. Glob. Change Biol. 15, 2935-2949 (2009).

8. von Lützow, M. et al. Eur. J. Soil Sci. 57, 426-445 (2006).

9. Kemmitt, S. J. et al. Soil Biol. Biochem. 40, 61-73 (2008).

\title{
CRYOSPHERE
}

\section{Arctic ice across the ages}

Perhaps the most defining feature of the Arctic Ocean today is the vast expanse of sea ice that coats the surface, choking straits and grounding on the polar coasts. The extent of sea ice typically fluctuates with the passing seasons. But over the past few decades, the thick, rugged sea ice that usually persists for years has given way to thin, nascent ice cover, which readily melts under the summer sun. This period of accelerated melting is unusual compared with the ice extent that was observed throughout the satellite era, and culminated in a record low extent of sea ice in late summer 2007. However, little is known about changes in sea ice coverage over the past few centuries, and even less is known about variability over millionyear timescales.

When glaciers scrape over the continents, they leave behind tell-tale signs: huge boulders dot the terrain, glacial till piles up and hills are carved into the landscape. However, traces of sea ice are often much harder to discern: Leonid Polyak of Ohio State University and colleagues (Quat. Sci. Rev. doi: 10.1016/ j.quatscirev.2010.02.010; in the press) sifted through masses of data - from dropstones to whale bones - to track the waxing and waning of Arctic sea ice for tens of millions of years.

According to their findings, the story of sea ice in the Arctic Ocean began 47 million years ago, when the climate was cooling following the bursts of rapid greenhouse warming that marked the late Palaeocene and early Eocene epochs. However, it probably wasn't until 13 or 14 million years ago that sea ice first acquired its perennial nature, although a return to slightly milder conditions one or two million years later brought sea-icefree conditions, at least seasonally, back

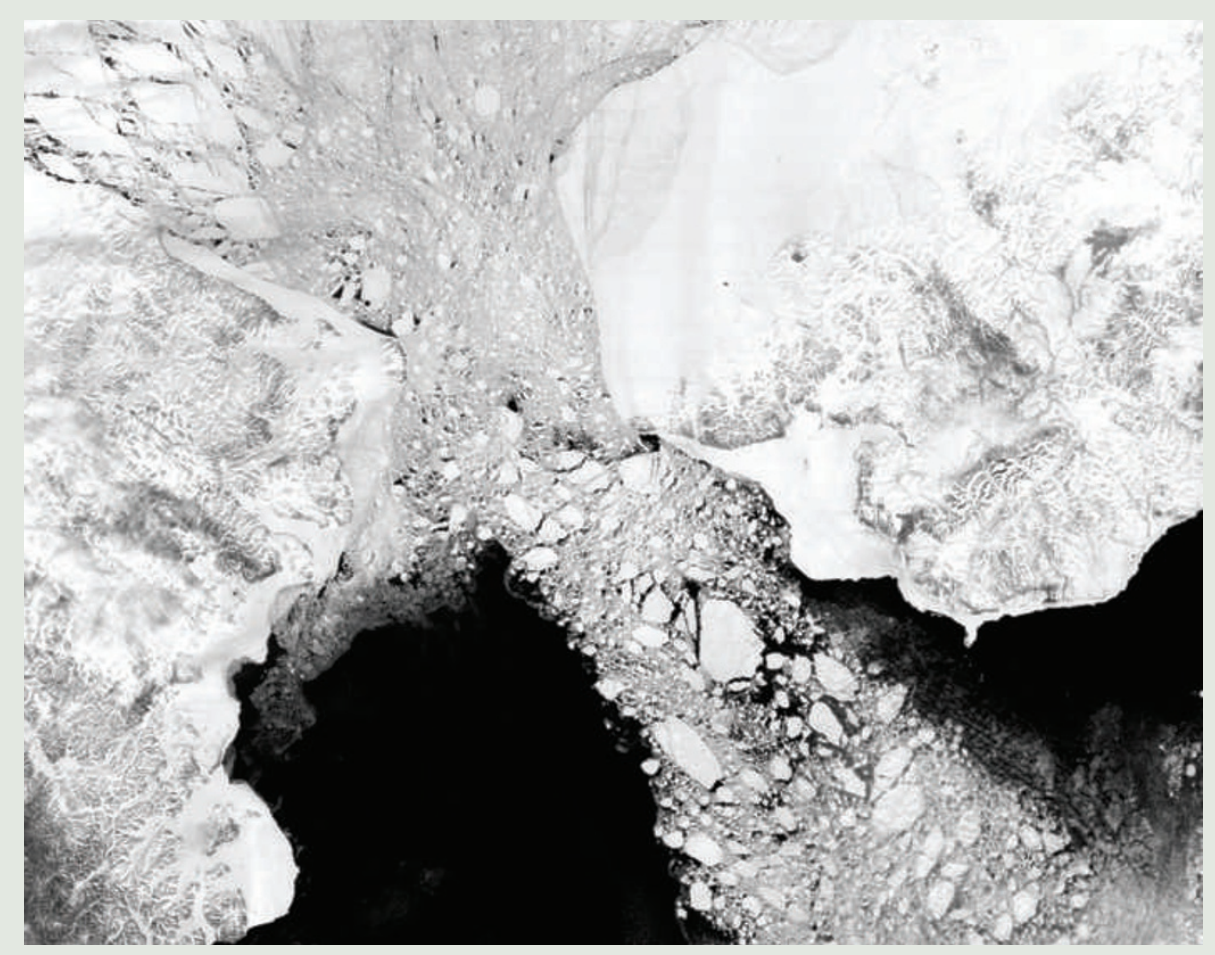

to the Arctic. This lasted until a substantial cooling occurred three million years ago.

Sea ice cover became the norm from 2 to 1.5 million years ago, with all indicators pointing to a stable, permanent ice pack throughout most of the following glacial periods. And this ice was probably quite impressive, ranging up to several hundred metres thick throughout parts, or even all, of the Arctic Ocean. The largest millennialscale warm events may have temporarily reduced the ice pack, but for only brief intervals in an otherwise monotonous record of ice cover.

However, the ice broke during the interglacials: summers during the last interglacial, about 125,000 years ago, may have been completely ice free. Sea ice extent was also reduced during the early Holocene, though not nearly as dramatically. It wasn't until about 5,500 years ago that thick, old ice became prevalent throughout the Arctic Ocean once again. There were a few cycles of sea ice growth and retreat in the following millennia, but none that rival the losses reported in the past few decades.

Polyak and his co-authors conclude that the ice loss of the past decade seems to be unprecedented in comparison with the variability observed over these millennial time-scales. 